\title{
Quality of soybean seeds submitted to different treatments and storage conditions
}

\section{Francielen Lima da Silva', Letícia Barão Medeiros², Fabiano Carlos Ferreira ${ }^{3}$, Géri Eduardo Meneghello², Francisco Amaral Villela², Tiago Zanatta Aumonde², Tiago Pedó}

\author{
'Universidade Federal do Rio Grande do Sul, Brazil \\ ${ }^{2}$ Universidade Federal de Pelotas, Brazil \\ ${ }^{3}$ Sementes Petrovina, Brazil
}

*Corresponding author: Letícia Barão Medeiros

\begin{abstract}
Chemical seed treatment is a recommended technique to protect seeds from pathogens that can affect their quality. The objective of this work was to analyse the quality of soybean seeds with different treatments under different storage temperatures. Seeds of cultivar 'M 8378 IPRO' produced in Mato Grosso, Brazil were used. A completely randomised design was used in a $4 \times 3$ twofactorial scheme. The seeds were treated with three different combinations of chemicals (fungicides, insecticides, polymer and drying powder) in addition to the control (untreated seeds) combined with three different storage temperatures $\left(13^{\circ} \mathrm{C}, 19^{\circ} \mathrm{C}\right.$ and uncontrolled temperature), with three repetitions. Quality was assessed by the germination test (TG), accelerated aging (AA), field emergence (FE), tetrazolium test (TZ) and isoenzyme analysis. The uncontrolled storage temperature negatively influenced the variables germination, accelerated aging and field emergence. The vigour and viability of the tetrazolium test showed that untreated seeds had better physiological quality than seeds with chemical treatment. The expression of isoenzymes showed a difference between treatments. Even with the stress caused by the seed treatment, this tool is very important for the initial protection of the seedlings.
\end{abstract}

Keywords: Glycine max; insecticide; post-harvest; seed quality; temperature.

\section{Introduction}

The soybean (Glycine max (L.) Merrill) crop is the most cultivated and consumed legume in the world. It is a source of protein used both in human and animal feed in addition to the pharmaceutical industry and other uses. In Brazil, it has great economic importance, with production in the 2019/2020 harvest exceeding 124 million tons (Conab, 2020), despite the impact on production caused by the drought in the southern region of the country during the last harvest, with productivity reduction of up to $60 \%$ of its production in the areas due to this climatic phenomenon.

High productivity rates are obtained with technical efficiency in all production processes (Gazolla Neto et al., 2012; Strobel et al., 2016; Zimmer et al., 2016). In this context, the seed is considered the most important agricultural input, because it takes to the field the genetic characteristics that determine the performance of the cultivar, at the same time it is responsible for the establishment of the appropriate plant stand, providing the basis for high yields to be achieved (Marcos Filho, 2015).

Thus, it is necessary to develop methods that preserve the quality of the seeds, which involves the set of their physical, sanitary, genetic and physiological attributes (Peske et al., 2019), to provide healthy and vigorous seedlings, obtaining adequate and uniform stands. The maintenance of seed quality will only be obtained from adequate storage and possibly optimised by seed treatment, decreasing the susceptibility to pathogens.

The demand for seed treatment has been increasing, to protect seeds and promote initial seedling development. The treatment aims to protect the seeds through the use of insecticides and fungicides and/or nutrition with the addition of micronutrients, which can improve the initial development, affecting both the physiological and economic aspects (Avelar et al., 2011), in addition to obtaining adequate populations in the field under stress conditions, as observed by Balardin et al. (2011) in the soybean crop with a water deficit.

In addition, adequate storage is a fundamental practice that can help to maintain the physiological quality of the seed and is also a method by which the viability of the seeds can be preserved and their vigour maintained until sowing (Demari et al., 2019; Olsen et al., 2016; Olsen et al., 2015). According to Cardoso et al. (2012), the deterioration process is inevitable, but it can be delayed depending on the storage conditions and the characteristics of the seed. Among the factors that affect quality during storage, temperature and water content of the seed are the most important.

Therefore, this research will help to observe the physiological quality of soybean seeds treated with different combinations of chemicals under different storage temperatures. 


\section{Results and discussion}

\section{Analysis of variance}

The results obtained by the analysis of variance indicated significant differences for the different treatments applied to the variables TZ (vigour), TZ (viability) and EF (Table 2). There was a significant difference for the variable germination $(G)$, accelerated aging (AA), TZ (viability) and field emergence $(E F)$ between the different storage temperatures evaluated. Field emergence (EF) had a significant effect on the interaction between experimental factors (Table 2).

\section{Germination}

The germination of soybean seeds did not present significant differences in the different temperatures for the four chemical treatments used. However, when treatments are analysed separately, the uncontrolled temperature showed the lowest averages for this variable (Figure 1a). According to Carvalho et al. (2014), soybean seeds stored under controlled temperature conditions maintain germination and vigour for a longer period, when compared to uncontrolled conditions, and, consequently, the physiological quality of the seeds is reduced more quickly. For accelerated aging, when the storage temperature was not controlled, the lowest averages are observed within each treatment (Figure 1b). The seed has a hygroscopic nature, so temperature and humidity are of great importance in determining its physiological quality during the storage period. Stresses caused by these factors can contribute to the deterioration of the seeds causing destabilisation in the activities of enzymes and the disruption and loss of integrity of the cell membrane system through the increase of reactive oxygen species (ROS), reducing the vigour of the seeds.

\section{Vigour and viability - tetrazolium}

The vigour of the tetrazolium test, at storage temperatures of 13 and $19{ }^{\circ} \mathrm{C}$, showed significant differences between the different chemical treatments (CT) applied (Figure 2a). The highest averages were obtained by the control treatment (T1) for the different temperatures, although $\mathrm{T} 3$ and $\mathrm{T} 4 \mathrm{did}$ not present a significant difference from $\mathrm{T} 1$ at $13{ }^{\circ} \mathrm{C}$ or $\mathrm{T} 3$ at $19{ }^{\circ} \mathrm{C}$ (Figure 2a). The CT may be related to one of the causes of stress in the seeds, being responsible for the release of free radicals, which can cause a decrease in the physiological potential of the seed lot.

The viability by the tetrazolium test showed a significant difference between the storage temperatures used in the different chemical treatments, as well as these also differed at the different temperatures. Untreated seeds (T1) showed higher averages for uncontrolled temperature and temperature of $13{ }^{\circ} \mathrm{C}$; however, both treatments $\mathrm{T} 3$ and $\mathrm{T} 4$ did not differ from T1 (Figure 2b). For T2, the temperature of $19{ }^{\circ} \mathrm{C}$ obtained the highest average and did not differ significantly from the temperature of $13{ }^{\circ} \mathrm{C}$. Although the other treatments did not present a significant difference for the three storage temperatures, it is known that to maintain the physiological quality of the seeds some precautions are recommended, among them the control of the temperature and relative humidity of storage.

In this sense, Dan et al. (2010) state that it is possible to have a phytotoxic effect due to the increase in the storage period of seeds treated with insecticides, a fact that could have occurred in this work since the seeds were stored for 90 days until the tests were performed.

\section{Field emergence}

For field emergence, at each storage temperature, the uncontrolled temperature showed the highest averages for $\mathrm{T} 2$ and $\mathrm{T} 1$, respectively. Regarding the temperature of $13^{\circ} \mathrm{C}$, the highest averages were obtained for $\mathrm{T} 1$ and $\mathrm{T} 3$, and for the temperature of $19{ }^{\circ} \mathrm{C}$, the highest averages were obtained for T2, T3 and T1. Considering the different temperatures within each treatment, we can observe, except for T2, that the lowest averages were obtained by the uncontrolled temperature, followed by the temperature of $19^{\circ} \mathrm{C}$. The study of the correlation between vigour tests and the establishment of seedlings in the field is frequently adopted to validate the potential behaviour quantified in the laboratory (Braz et al., 2009; Leal et al., 2012).

\section{Isoenzymes}

The expression of the isoenzyme esterase (EST) was altered in seedlings under the most varied seed treatments (Figure 3). T4 did not show band expression; however, there was a greater number of bands in T3 compared to seedlings without treatment (T1), being more intense at $13{ }^{\circ} \mathrm{C}$. The greatest expression of esterase is related to stresses caused in seeds and seedlings (Pedó et al., 2016), being related to the reduction of seed vigour, as this enzyme is involved in ester hydrolysis reactions (Santos et al., 2005). The change in the expression pattern of the isoenzyme esterase can result in changes in the cell membrane system in the most varied environmental conditions compared to the controls (Aumonde et al., 2013; Pedó et al., 2015).

The isoenzyme peroxidase (PO) changed the expression of the number and intensity of the bands with the different treatments and temperatures (Figure 4). Seedlings originated from the three environmental conditions combined with four chemical treatments, showed peroxidase expression at temperatures of 13 and $19{ }^{\circ} \mathrm{C}$, compared to the uncontrolled temperature treatment, except for T3. Thus, the increase in peroxidase expression may be related to increased activity due to the increase in the production of free radicals (Pedó et al., 2016) caused by temperatures and chemical treatments. The accumulation of these potentially toxic compounds may have caused the loss of selectivity of the cell membrane system (Aumonde et al., 2013).

On the other hand, the isoenzyme malate dehydrogenase (MDH) showed a slight intensification of the bands (Figure 5). It showed no expression for $\mathrm{T} 3$, and had greater intensity and expression in $\mathrm{T} 2$ at $19{ }^{\circ} \mathrm{C}$. The enzyme malate dehydrogenase is associated with the biosynthesis of oxaloacetate, important in the synthesis of amino acids (Pedó et al., 2016). In addition, it is important to note that it is an important enzyme in cellular respiration (Santos et al., 2005), because it catalyses the conversion of malate into oxaloacetate, having an important function in the production of NADH for the Krebs cycle (Tunes et al., 2011), a product fundamental in the production of ATP and intermediate compounds essential to the function of cells (Taiz et al., 2013). 
Table 1. Chemical treatments used, with the respective doses.

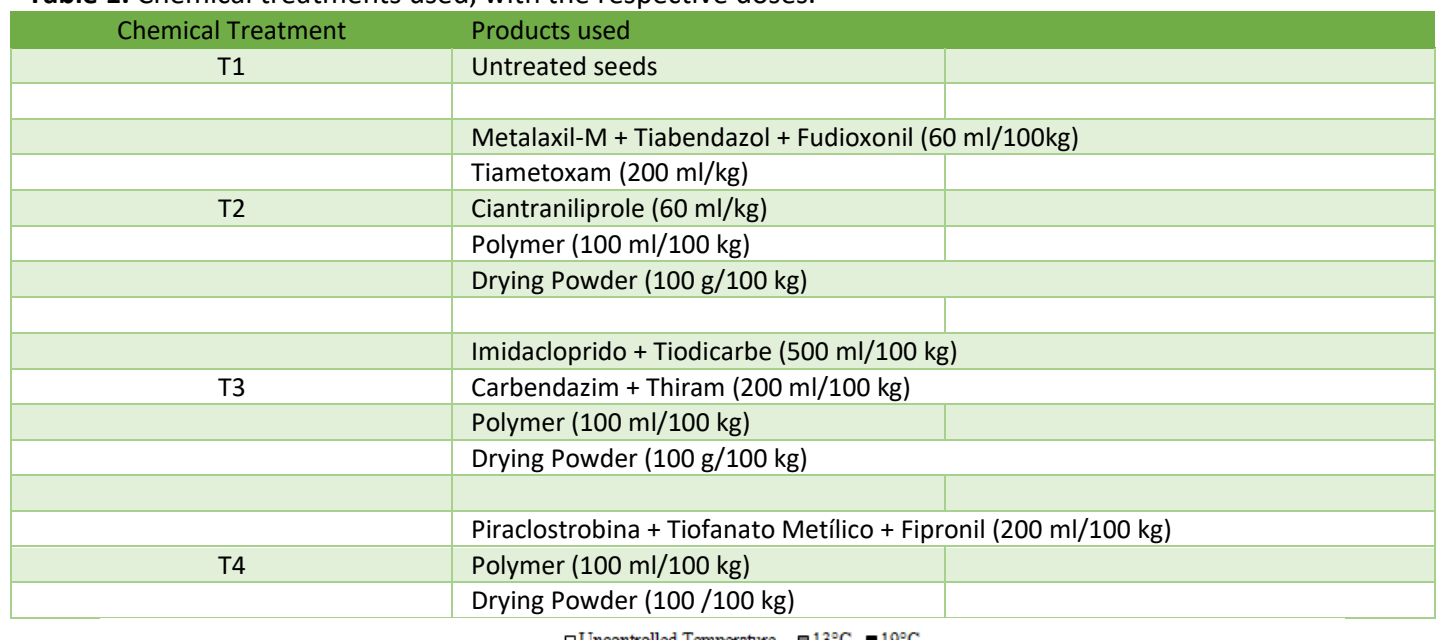
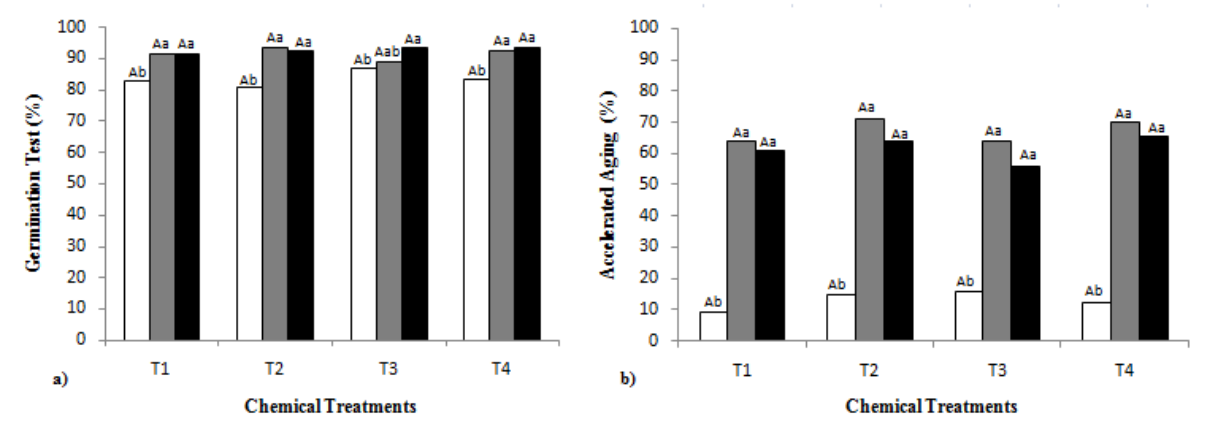

Fig 1. Germination Test (a) and accelerated aging (b); means followed by the same capital letter, setting storage temperature (uncontrolled, $13{ }^{\circ} \mathrm{C}$ or $19{ }^{\circ} \mathrm{C}$ ), do not differ by Tukey's test at $5 \%$ probability of error; means followed by the same lower-case letter, setting chemical treatments ( $\mathrm{T} 1, \mathrm{~T} 2, \mathrm{~T} 3$ or $\mathrm{T} 4)$, do not differ by Tukey's test at $5 \%$ probability of error.

Table 2. Average squares of the analysis of variance for soybean seeds submitted to different treatments under different storage temperatures.

\begin{tabular}{|l|l|l|l|l|l|l|}
\hline Source of Variation & DF & GT & AA & TZ (Vigour) & TZ (Viability) & EF \\
\hline Chemical treatment $(\mathrm{Ct})$ & 3 & $2.55^{\text {ns }}$ & $66.26^{\text {ns }}$ & $1250.69^{*}$ & $149.44^{*}$ & $39.63^{*}$ \\
\hline Temperature (Te) & 2 & $293.53^{*}$ & $10671.03^{*}$ & $197.53^{\text {ns }}$ & $189.08^{*}$ & $189.58^{*}$ \\
\hline Ct $x$ Te & 6 & $14.49^{\text {ns }}$ & $27.4^{\text {ns }}$ & $36.75^{\text {ns }}$ & $7.27^{\text {ns }}$ & $31.21^{*}$ \\
\hline Residue & 22 & 7 & 26.95 & 104.22 & 17.3 & 6.48 \\
\hline Total & 35 & & & & & \\
\hline SD & & 2.65 & 5.19 & 10.21 & 4.16 & 2.53 \\
\hline CV (\%) & & 2.97 & 10.98 & 14.84 & 4.79 & 3.18 \\
\hline
\end{tabular}

DF - Degrees of freedom; GT - Germination test; AA Accelerated aging; TZ - Tetrazolium test. *Significant F test at 5\% probability.

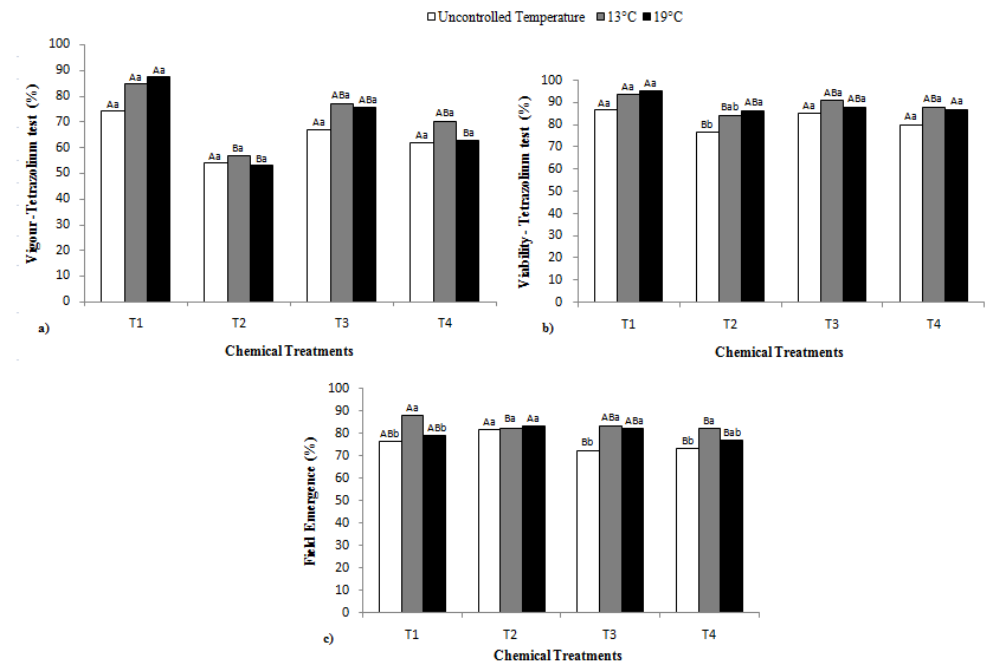

Fig 2. Vigour-tetrazolium (a), viability-tetrazolium (b) and field emergence (c); means followed by the same capital letter, at each storage temperature (uncontrolled, $13^{\circ} \mathrm{C}$ and $19{ }^{\circ} \mathrm{C}$ ), do not differ by Tukey's test at $5 \%$ probability of error; means followed by the same lowercase letter, in each chemical treatment ( $11, \mathrm{~T} 2, \mathrm{~T} 3$ or $\mathrm{T} 4)$, do not differ by Tukey's test at $5 \%$ probability of error. 

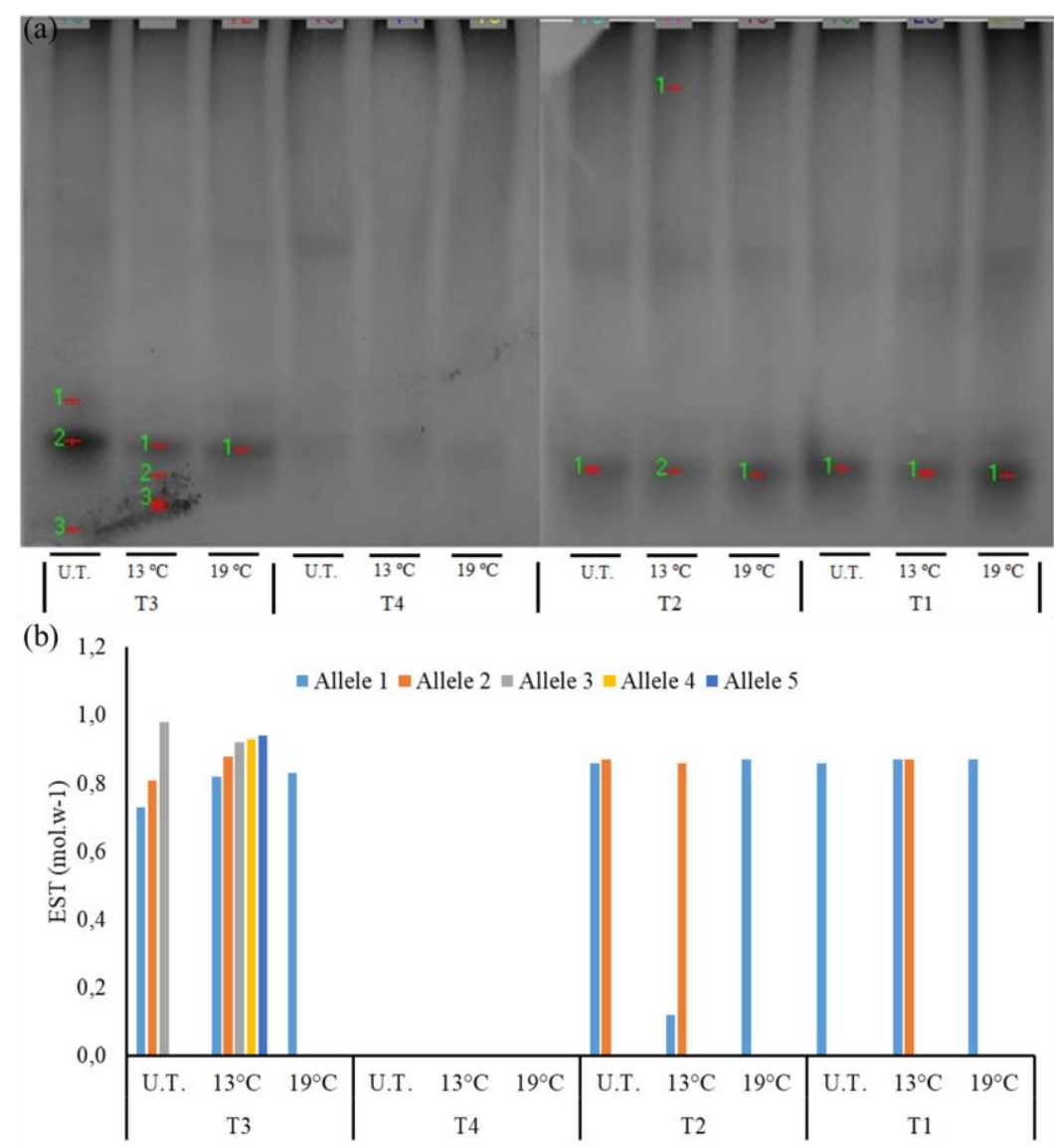

Fig 3. Isoenzyme expression of esterase gel (a) and molecular mass of alleles (b) in soybean seedlings under different seed treatments; these are: T3-Lane 1 to 3 (uncontrolled temperature, $13^{\circ} \mathrm{C}$ and $19^{\circ} \mathrm{C}$ ), T4-Lane 4 to 6 (uncontrolled temperature, $13^{\circ} \mathrm{C}$ and $19^{\circ} \mathrm{C}$ ), T2-Lane 7 to 9 (uncontrolled temperature, $13^{\circ} \mathrm{C}$ and $19^{\circ} \mathrm{C}$ ) and $\mathrm{T} 1$-Lane 10 to 12 (uncontrolled temperature, $13^{\circ} \mathrm{C}$ and $19^{\circ} \mathrm{C}$ ), respectively.
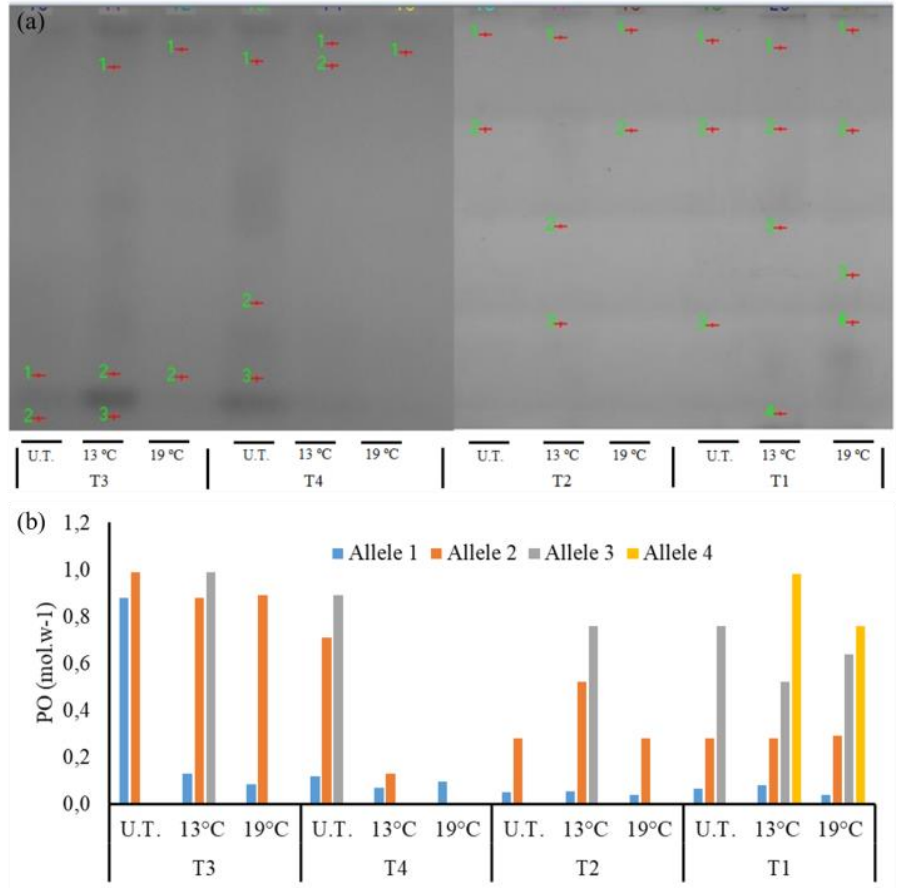

Fig 4. Isoenzyme expression of peroxidase gel (a) and molecular mass of alleles (b) in soybean seedlings under different seed treatments; these are: T3-Lane 1 to 3 (uncontrolled temperature, $13^{\circ} \mathrm{C}$ and $19^{\circ} \mathrm{C}$ ), T4-Lane 4 to 6 (uncontrolled temperature, $13^{\circ} \mathrm{C}$ and $19^{\circ} \mathrm{C}$ ), T2-Lane 7 to 9 (uncontrolled temperature, $13^{\circ} \mathrm{C}$ and $19^{\circ} \mathrm{C}$ ) and T1-Lane 10 to 12 (uncontrolled temperature, $13^{\circ} \mathrm{C}$ and $19^{\circ} \mathrm{C}$ ), respectively. 

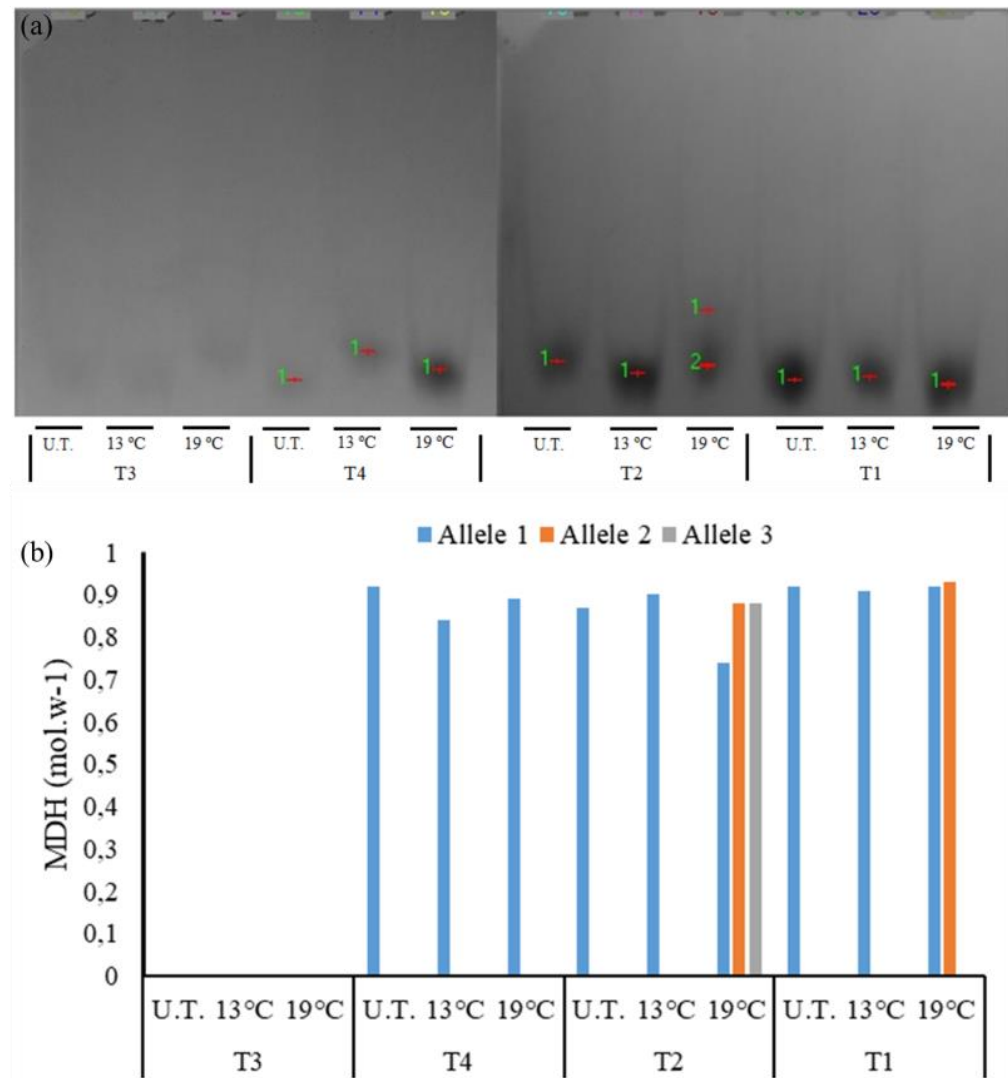

Fig 5. T3: Isoenzyme expression of malate dehydrogenase gel (a) and molecular mass of alleles (b) in soybean seedlings under different seed treatments; these are: T3-Lane 1 to 3 (uncontrolled temperature, $13^{\circ} \mathrm{C}$ and $19^{\circ} \mathrm{C}$ ), T4-Lane 4 to 6 (uncontrolled temperature, $13^{\circ} \mathrm{C}$ and $19^{\circ} \mathrm{C}$ ), T2-Lane 7 to 9 (uncontrolled temperature, $13^{\circ} \mathrm{C}$ and $19^{\circ} \mathrm{C}$ ) and $\mathrm{T} 1$ - Lane 10 to 12 (uncontrolled temperature, $13^{\circ} \mathrm{C}$ and $19^{\circ} \mathrm{C}$ ), respectively.

\section{Materials and methods}

The experiment was conducted at the Didactic Laboratory of Seed Analysis, of the Post-Graduate Program in Seed Science and Technology, Department of Phytotechnics, Eliseu Maciel Agronomy School (FAEM), Federal University of Pelotas (UFPel), Pelotas, Brazil. Seeds of the soybean cultivar 'M 8378 IPRO' were used from the production field of the state of Mato Grosso, Brazil, from the 2018/19 harvest.

\section{Seed treatment and storage conditions}

The seeds were chemically treated using three different product combinations (fungicides, insecticides, polymer and drying powder), in addition to the untreated seed, as shown in Table 1. For each experimental unit, $5 \mathrm{~kg}$ of seeds were treated for about one minute, using a Momesso Model ARKTOS L-5K laboratory seed-treatment machine.

The seeds and their respective treatments were stored for 90 days in three storage conditions: Condition 1uncontrolled temperature and relative humidity, Condition 2-temperature of $13 \pm 1{ }^{\circ} \mathrm{C}$ and $\mathrm{RH} 55 \pm 5 \%$ and Condition 3 -temperature of $19 \pm 1{ }^{\circ} \mathrm{C}$ and $\mathrm{RH} 55 \pm 5 \%$. Then, the following tests were performed.

\section{Laboratory and field tests}

\section{Germination test (GT)}

Four replications of 200 seeds were used, divided into four subsamples of 50 seeds, which were sown on Germitest paper, moistened with distilled water, in the proportion of 2.5 times the dry paper mass and kept in a germinator set at $25{ }^{\circ} \mathrm{C} \pm 2{ }^{\circ} \mathrm{C}$. The count of normal seedlings was carried out eight days after the test was installed and the results are expressed as a percentage (Brasil, 2009).

\section{Accelerated aging (AA)}

Plastic or acrylic boxes $(11 \mathrm{~cm} \times 11 \mathrm{~cm} \times 3 \mathrm{~cm})$ were used as individual compartments. The relative humidity inside these boxes was obtained by adding $40 \mathrm{ml}$ of saturated sodium chloride solution (75\% U.R. environment) to the bottom of each box, as described by Marcos-Filho et al. (2000). The samples of each treatment are distributed in a single layer covering the entire surface of the wire mesh suspended inside each box. Accelerated aging was conducted at $41^{\circ} \mathrm{C}$ for 48 hours inside the BOD. Then, the germination test was conducted at $25^{\circ} \mathrm{C}$ for four days, the average percentage of normal seedlings for each experimental unit was evaluated.

\section{Emergence in the field (EF)}

Field emergence was evaluated by sowing 100 seeds per experimental unit, in a field with soil and sand substrate. The counting of normal seedlings was performed at 14 days after sowing, with the results expressed as a percentage (Nakagawa, 1999). 


\section{Tetrazolium test (TZ)}

The seeds were evaluated individually, classifying them into vigorous seeds and viable seeds according to the methodology described by França-Neto and Krzyzanowski (2018).

\section{Molecular analysis (MA)}

The determination of isoenzymes was obtained by collecting 10 seedlings from the germination test, eight days after sowing. The expression rates of the isoenzymes esterase (EST), malate dehydrogenase (MDH) and peroxidase (PO) were determined by the vertical electrophoresis system in polyacrylamide gel. The seedlings were macerated separately in porcelain mortars in an ice bath. Electrophoresis was performed on 7\% polyacrylamide gels, applying $20 \mu \mathrm{L}$ of each sample. The staining systems used were described by Scandálios (1969) and Alfenas (1998). For the interpretation of the results, the presence or absence and intensity of each of the electrophoretic bands were taken into account, followed by the evaluation of the molecular mass of each band using Gelpro software.

\section{Statistical analysis}

The data obtained were subjected to analysis of variance and comparison of means by the Tukey test at $5 \%$ probability.

\section{Conclusion}

The uncontrolled storage temperature negatively influenced germination, accelerated aging and field emergence. Untreated seeds had better physiological quality than seeds with chemical treatment in the tetrazolium test. The T4 treatment (pyraclostrobin + methyl thiophanate + fipronil) did not affect the expression of esterase isoenzymes and had a very low effect on peroxidase. However, for the isoenzyme malate-dehydrogenase, T3 (imidacloprid + tiodicarb - carbendazim + thiram) did not show any expression, thus demonstrating that the stress caused by the seed treatment in T4 and T3 was less than the other treatments when observed the action of these isoenzymes, respectively. Even with the stress caused by the seed treatment, this tool is very important for the initial protection of the seedlings.

\section{Acknowledgments}

APROSMAT - Associação dos produtores de Sementes de Mato Groso/Mato Grosso Seed Producers Association and FASE-Fundo de Apoio à Cultura da Semente/Fund to Support Seed Culture.

\section{References}

Alfenas AC (1998) Eletroforese de isoenzimas e proteínas afins: fundamentos e aplicações em plantas e microrganismos. Ambiência, 9 (2): 289-298.

Aumonde TZ, Pedó T, Martinazzo EG, Borella J, Villela FA (2013) Expressão isoenzimática de sementes e plântulas de arroz-vermelho sob ação do extrato de duas espécies Araceae. Rev. Cienc.Agrar./Amaz. J Agric Envir Sci. 56: 283286.

Avelar SAG, Baudet L, Peske ST, Ludwig MP, Rigo GA, Crizel RL, Oliveira S (2011) Storage of soybean seed treated with fungicide, insecticide and micronutrient and coated with liquid and powered polymer. Cienc Rural. 41 (10): 17191725.

Balardin RS, Silva FDL, Debona D, Corte GD, Favera DD, Tormen NR (2011) Tratamento de sementes com fungicidas e inseticidas como redutores dos efeitos do estresse hídrico em plantas de soja. Cienc Rural. 41 (7): 1120-1126.

Brasil. Ministério da Agricultura e da Reforma Agrária (2009) Regras para análise de sementes. Brasília: SNDA/DNDV/CLAV.

Braz MRS, Rossetto CAV (2009) Correlação entre testes para avaliação da qualidade de sementes de girassol e emergência das plântulas em campo. Cienc Rural. 39 (7): 2004-2009.

Cardoso RB, Binotti FFS, Cardoso ED (2012) Potencial fisiológico de sementes de crambe em função de embalagens e armazenamento. Pesq Agrop Trop. 42: 272 278.

Carvalho ER, Mavaieie DPRM, Oliveira JA, Carvalho MV, Vieira AR (2014) Alterações isoenzimáticas em sementes de cultivares de soja em diferentes condições de armazenamento. Pesq Agrop Bras. 49 (12): 967-976.

CONAB. Companhia Nacional de Abastecimento. Acompanhamento da safra brasileira de grãos, 2020. Disponivel em: <https://www.conab.gov.br/infoagro/safras/graos>.

Dan LGM, Dan HA, Barroso ALL, Braccini AL (2010) Qualidade fisiológica de sementes de soja tratadas com inseticidas sob efeito do armazenamento. Rev Bras Sem. 32 (2): 131139.

Demari GH, Szarescki VJ, Carvalho IR, Silva TA, Gehling VM, Olsen D, Martins TS, Lautenchleger F, Santos LA, Schuch LOB, Meneghello GE, Souza, VQ, Pedó T, Villela FA, Aumonde TZ (2019) Storage of Soybean Seeds and Addition of Insecticide and Micronutrients. J Agric Sci. 11: 553-560.

França-Neto JB, Krzyzanowski FC (2018) Metod teste tetraz semen soja. 1ed. n.406. 108p

Gazolla Neto A, Aumonde, TZ, Olsen D, Pedó T, Villela FA (2012) Níveis de umidade do solo de várzea e seus efeitos sobre a emergência e crescimento inicial de plântulas de soja. Inf Abrates. 22: 28-31.

Leal CCP, Torres SB, Nogueira NW, Tomczak VE, Beneditom CP (2012) Validação de testes de vigor para sementes de rúcula (Eruca sativa L.). Rev Bras Bioci. 10 (3): 421-424.

Marcos-Filho J, Novembre ADLC, Chamma, HMCP (2000) Tamanho da semente e teste de envelhecimento acelerado para soja. Sci Agric. 57 (3): 473- 482.

Marcos-Filho J (2015) Fisiologia de sementes de plantas cultivadas. 2. ed., Londrina: ABRATES, 660p.

Nakagawa J (1999) Testes de vigor baseados na avaliação das plântulas. In: Vieira RD, Carvalho NM. (ed) Test Vigor Sem. 49-85.

Olsen D, Pedó T, Koch F, Martinazzo EG, Aumonde TZ, Villela FA (2016) Tratamento de sementes com bioestimulante: vigor e isoenzimas de plântula de arroz de sequeiro sob restrição hídrica. Agrarian. (Online). 9: 296-302.

Olsen D, Pedó T, Aisenberg GR, Aumonde TZ, Villela FA (2015) Physiological traits of the initial growth in rainfed rice plants in response to seed treatment with micronutrients. Biosci J. 31: 1118-1123. 
Pedó T, Koch F, Gazolla Neto A, Olsen D, Castro MAS, Martinazzo EG, Aumonde TZ, Villela FA (2016) Expressão isoenzimática e do vigor de sementes de centeio sob efeito da restrição hídrica. Pesq Agrop Pernamb. 21: 17-23.

Pedó, T, Martinazzo EG, Aumonde TZ, Villela FA (2015) Desempenho de sementes, vigor e expressão isoenzimática em plântulas de teosinto (Euchlaena mexicana Schrader) sob efeito da restrição hídrica. Rev Bras Bioci. (Online). 13: 5-9.

Peske ST, Villela FA, Meneghello GE (2019) Sementes: Fund Cient Tecnol. 4Ed. Revisada, Atualizada e Ampliada. 579p.

Santos CMR, Menezes NL, Villela FA (2005) Modificações fisiológicas e bioquímicas em sementes de feijão no armazenamento. Rev Bras Sem. 27 (1): 104-114.

Scandálios JG (1969) Genetic control of multiple molecular forms of enzymes in plants: a rewiew. Bioci Genet. 3 (1): 37-79.
Strobel T, Koch F, Aisenberg GR, Szarescki VJ, Carvalho IR, Nardino M, Souza VQ, Villela FA, Pedó T, Aumonde TZ (2016) Physical and physiological quality of soybean seeds harvested under different trial after storage periodsystems. Aust J Basic Appl Sci. 10: 124-130.

Taiz, L, Zeiger, E (2013) Fisiol Veg. 5a ed. Porto Alegre: Artmed. $954 \mathrm{p}$

Tunes LM, Badinelli PG, Barros ACSA, Meneghello GE, Amarante L (2011) Influência dos diferentes períodos de colheita na expressão de isoenzimas em sementes de cevada. Rev Ceres, Viçosa. 58 (2): 178-184.

Zimmer G, Koch F, Carvalho IR, Szarescki VJ, Demari GH, Nardino M, Follmann N, Souza VQ, Aumonde TZ, Pedó T (2016) Seed quality and initial performance of seedlings of soybean produced off-season in rio grande do sul, brazil. Intern J Cur Res. 8: 40325-40329. 